\title{
Reconstructing the Performance of Pakistan's Political Economy: Another Paradigm
}

\section{Inayat Ullah Mangla*}

\begin{abstract}
This paper looks at the major factors limiting economic growth in Pakistan. The paper then analyzes the structural problems faced by Pakistan today and goes on to discuss the challenges facing monetary policy makers in Pakistan as well as the problem of budget and trade deficits. The paper concludes with a discussion on the key institutional changes needed in Pakistan.
\end{abstract}

Keywords: Economic Growth, Budget Deficit, Trade Deficit, Pakistan.

JEL Classification: F49, F50.

\section{Introduction}

When I started thinking about this paper in the dull, cold, snowy winter of Michigan, several thoughts and approaches came to mind. The first concerned where to start Pakistan's performance and growth storyperhaps in 1958, when the second martial law was imposed by Ayub's regime. The country's macroeconomic performance on a relative basis was fairly good during the three military regimes it experienced-under Ayub in the 1960s, under Zia in the 1980s, and under Musharraf in the 2000scompared its performance under politically elected governments. But that approach sends the wrong policy message for the political economy and for sustained economic growth. High growth in these regimes may legitimize their existence since these higher growth rates can, at best, be attributed to what economists call the benefits of positive externalities.

A second approach was to look at these issues using a purely econometric framework either by invoking the standard regression techniques or by simply comparing the actual and simulated data (see, for instance, Government of Pakistan, 2010a; Khan \& Din, 2011; and Malik \&

\footnotetext{
* Professor of Finance and Commercial Law, Haworth College of Business, Western Michigan University (USA).
} 
Ahmad, 2009). This would mean analyzing several imbalances in the economy by looking at the savings-investments gap, actual vs. potential output of the economy, trade gaps, and budget deficit gap, etc.; and the role of fiscal and monetary policies in fine-tuning and combating these gaps.

In recent years, some of the elaborate studies carried out at different places-the Pakistan Institute of Development Economics (PIDE), Social Policy Development Centre, Planning Commission, the Lahore School of Economics, and Quaid-i-Azam University-convinced me to look at the anatomy of growth from a different perspective, including theirs. In the presence of these excellent studies, I have decided not to run my own regressions and instead focus on adding a few shades to the existing excellent research.

Today, we all know the macroeconomic ills of Pakistan's economy, which is characterized by stagflation, (or to be exact low growth and high inflation), huge twin budget and trade deficits, crumbling state-owned enterprises, booming domestic and external debt, energy shortages, political unrest, the ongoing war on terrorism, etc. to name a few. The public mood in Pakistan has soured badly to the point where even upper-middle-class people have begun to complain that things are seriously amiss.

No one disputes that, over the long term, macro-performance in the last 64 years has created wealth and perhaps better lives for a few million people, but benefits of growth have still not spread or trickled down widely among the country's 170 million residents. Pakistan has increased its gross domestic product (GDP) and per capita income, and improved some other social indicators, but in relative terms, the glass is half full and half empty, especially in terms of attaining a sustainable growth path for the economy and "resilience" to shocks.

The question we need to address is, why policies or their effects on the economy have for so long been so unstable and erratic? Why has each successive policy package not only been abandoned but sometimes reversed? Why has it so frequently been possible to assemble blocking coalitions (what some economists have called "rent-seeking"), capable of vetoing policies that threaten their interests, but subsequently incapable of holding together to implement some positive alternatives.

The characteristics of Pakistan's political economic structure might help us explain this national economic malaise. To keep things in perspective, consider the following two statements: 
With inflation still hovering around 8\%-despite the monetary tightening over the last two years-a fiscal deficit threatening to cross $4.2 \%$ of GDP and the reversal of the current account surplus into a large deficit that could touch $5.5 \%$ of GDP, there are understandably fears that the macroeconomic stability achieved after a long and hard struggle, with a fair sprinkling of luck thrown in by the events of 9/11, has been lost (Kardar, 2007).

The second is from Haque (2010):

Never has there been a more pressing need in Pakistan's history to search for a new model, however at the outset it should be said that if there has to be a new development framework, it should by all means take account of the damages caused by recent flash floods, security and governance issues currently facing the country. In the new development framework, [the] private sector should be the growth-driver in open market environment that rewards efficiency, innovation and entrepreneurship, while the government is [a] facilitator that protects public interest and rights, provides public goods, enforces laws, punishes exploitative practices, and operates with transparency and accountability (p. 45).

After reading the first quotation, we should ask where we stand after four years. Here is a summary snapshot from the State Bank of Pakistan (SBP)'s annual report (October 2010):

... some key reforms failed to gather traction: (1) persistent disagreements led to the deferment of a proposed expansion of the tax net through the introduction of a broad based GST, (2) the proposed restructuring of public sector enterprises, to improve efficiency and lower the fiscal burden, did not take place; and (3) after some initial work, there was little or no progress in either resolving the energy sector debt chain (the so-called "circular debt" problem" or substantially improving electricity supply. The principal structural problem however was the weak fiscal performance; the fiscal deficits bounced back to 6.3 percent of GDP in [fiscal year] FY10. 
... The initial Rs 1.6 trillion tax revenue targets for FY10 had looked optimistic, incorporating a record 29.8 percent annual growth, compared with an average growth of 14.6 percent over the preceding five years... [This was] not very surprising, given the absence of any significant measures to expand the tax base or to exploit the existing tax base more effectively.

The slippage on the expenditure side was more disappointing. There are significant rigidities in government spending, including debt-servicing, defense, the government salary bill, etc. However, there appears little evidence of efforts to contain the growth in even the discretionary components.

... A large part of the rise in subsidies and PSEs losses is a function of the continuing government intervention in market pricing of goods and services. Such interventions are typically undesirable, as they encourage over-consumption, reduce incentives to increase efficiency, and lead to misallocation of resources (State Bank of Pakistan, 2010).

This is the summary performance of our macroeconomic activity after four years. The Pakistan Economic Survey for 2009/10 puts it mildly:

Checking inflation... involves limiting borrowing by the government and the public sector... But there are major risks to the growth and stabilization prospects if there is...

... non-implementation of the reform of the GST, leading to a VAT, or other significant tax broadening measures... Failing to reform public sector enterprises, including the power sector, with no resolution of the energy circular debt issue; continued overhang of commodity financing debt stock, if unchecked, threatens to constrict access to bank credit by the private sector, while simultaneously increasing the interest rates in the economy (Government of Pakistan, 2010b).

Looking at the country's performance since 2010, most macroindicators show mixed trends. 
- The inflationary impact is also reflected in the prices of raw material and finished products.

- The record volume of remittances worth USD11.2 billion in FY2011 has improved savings.

- The gross total investment of Pakistan has come down to 13.4 percent of GDP in FY2011. The improvement in savings has not reflected the investment trend, which is falling.

- The gap between national savings and investment as a percent of GDP has become marginally positive. Since this positive gap is mostly due to failing investment, it cannot be considered an encouraging development from the perspective of reviving economic activities and sustaining high growth in the medium term.

- Whatever is being saved in financial institutions is being invested in nonproductive government papers, and does not help the economy perform better.

In the wake of these developments and other policy differences with the government, the SBP's governor resigned in the summer of 2011. Thus, the scope of this paper is as follows: Section 2 provides an overview of Pakistan's macroeconomic performance over the last two decades. Section 3 looks at a new paradigm from an institutional and political economic structure that may explain the quasi-deterioration of our macro-performance. Section 4 concludes the study by outlining some of major challenges for macroeconomic policy, policymakers, political leaders for institution building, and planning leaders.

\section{Macro-Performance Indicators}

In Pakistan, as in some other developing countries, an import substitution policy prevailed until the late 1960s, with the state playing a dominant role in the development process. This provided a strong stimulus to investment and growth. Investment levels and GDP growth rates doubled during 1960-65, but such a policy also created distortions in the economy that were aggravated by the nationalization policies of the 1970s. The second phase (1973-88) reflected the national pursuit of a form of "Islamic socialism" and social justice. The third phase, "liberalization," marks the shift toward a market-based economy and is characterized by the liberalization of external accounts and the removal of 
regulatory barriers on private and foreign investments. Initially, "privatization" and "liberalization" were dirty words but they have gained acceptance over time.

Pakistan's economic liberalization was triggered in the early 1990s, especially in the financial sector. The deregulation of the financial sector occurred quickly and with reasonable success, and contributed to the growth of the economy. The value of the services sector has increased as a proportion of GDP, rising to 53 percent in 2010 from less than 30 percent in 1990. However, many such fast-growing areas-finance, telecommunication, and technology-employ relatively few workers and rely heavily on skilled labor.

India's experience in this sector has been similar; it employs just 2.5 million workers in information technology-a tiny fraction of the total labor force. These reforms have been pursued persistently-some would argue even inconsistently-since the 1990s. Amjad (2003) is critical of the sequencing and timing of these reforms and their impact on poverty reduction. Some of the inefficiencies and weaknesses that were typical of banks' operations in the pre-reforms era have been reduced to some extent. Pakistan's economy has realized the dividend of these reforms in the shape of a healthier and stronger banking system. Up till 2007, liberalization and deregulation-the core pillars of the reform measureshave served well in enhancing the size of the banking industry, both in terms of the number of banks and growth in credit.

Historically, infrastructure and development projects fall in the public sector's domain of activities in Pakistan. However, in the 1990s, we saw a shift in this area, with a growing interest by the private sector in undertaking such projects. Based on the growth of the financial sector, it was hoped that there might exist immense potential for financial institutions to finance such infrastructure projects built on public-private partnerships or even exclusively in the private sector. This would help diversify activities and enhance earnings. However, this did not materialize due to several political developments in the last two decades; more recently, we have tended to blame the global financial crisis.

The financial system of any country has an intrinsic relationship and needs to be shaped in accordance with its broader economic objectives. Considering this interdependence, it is imperative that we assess key macroeconomic objectives in the context of the financial sector. Simultaneously, what is often overlooked is that the foundations of a 
market economy and those of capitalism are: the rule of law and an independent judiciary; efficient governance; a private sector able to thrive free of state favor; and competition and open borders for goods, people, and capital.

In evaluating the country's macroeconomic performance, we are dealing with the behavior of very large economic aggregates, their relationships and determinants, and a set of relative prices such as the inflation rate and exchange rate. Macroeconomic policies refer to those policies that influence macro-aggregates and relative prices. Table 1 provides selected macroeconomic/financial indicators for Pakistan for the period 1991-2010. 

Table 1: Selected Macroeconomic /Financial Indicators for Pakistan

\begin{tabular}{|c|c|c|c|c|c|c|c|c|c|c|c|}
\hline & 1 & 2 & 3 & 4 & 5 & 6 & 7 & 8 & 9 & 10 & 11 \\
\hline Year & Yn (\%) & ỳ (\%) & $\mathbf{P}(\%)$ & $M_{2}(\%)$ & M (\%) & $R_{D}(\%)$ & $\mathbf{R}_{\mathrm{c}}(\%)$ & ER & REER & BD/GDP (\%) & TD (\%) \\
\hline FY1991 & 15.56 & 3.50 & 12.28 & 16.05 & 3.76 & 10.00 & 7.29 & 21.90 & 116.0 & 8.30 & -4.58 \\
\hline FY1992 & 15.72 & 6.46 & 9.58 & 23.26 & 13.68 & 10.00 & 7.64 & 24.72 & 114.4 & 7.54 & -6.32 \\
\hline FY1993 & 9.79 & 1.51 & 8.34 & 16.35 & 8.01 & 10.00 & 7.51 & 25.70 & 114.0 & 5.73 & -3.83 \\
\hline FY1994 & 15.30 & 3.22 & 12.12 & 16.67 & 4.55 & 10.00 & 11.00 & 30.12 & 111.4 & 4.84 & -4.16 \\
\hline FY1995 & 18.33 & 5.29 & 12.99 & 15.91 & 2.92 & 15.00 & 8.69 & 30.95 & 110.7 & 4.47 & -5.80 \\
\hline FY1996 & 11.69 & 3.76 & 8.04 & 12.94 & 4.90 & 17.00 & 11.66 & 35.27 & 107.3 & 5.34 & -4.99 \\
\hline FY1997 & 13.11 & 0.61 & 12.56 & 11.51 & 10.50 & 20.00 & 11.40 & 40.19 & 108.8 & 5.66 & -3.01 \\
\hline FY1998 & 9.66 & 2.35 & 7.26 & 13.57 & 6.31 & 18.00 & 12.10 & 44.55 & 106.7 & 4.92 & -3.35 \\
\hline FY1999 & 9.33 & 3.68 & 5.70 & 5.97 & 0.27 & 16.50 & 10.71 & 61.93 & 99.5 & 6.26 & -2.40 \\
\hline FY2000 & 6.30 & 3.82 & 2.69 & 8.96 & 6.27 & 13.00 & 9.04 & 59.72 & 100.0 & 5.68 & -1.70 \\
\hline FY2001 & 8.35 & 2.57 & 5.88 & 8.58 & 2.69 & 13.00 & 8.57 & 57.75 & 91.5 & 4.11 & -0.41 \\
\hline FY2002 & 8.20 & 4.55 & 3.03 & 14.34 & 11.31 & 10.00 & 8.49 & 58.00 & 94.8 & 7.40 & -0.53 \\
\hline FY2003 & 13.71 & 8.51 & 4.54 & 16.57 & 12.02 & 7.50 & 5.53 & 59.96 & 91.8 & 3.27 & -1.23 \\
\hline FY2004 & 11.45 & 4.82 & 6.57 & 17.92 & 11.35 & 7.50 & 2.14 & 60.36 & 91.1 & 2.44 & -4.12 \\
\hline FY2005 & 16.51 & 7.67 & 9.35 & 17.64 & 8.30 & 7.50 & 2.70 & 60.65 & 93.995 & 1.71 & -6.67 \\
\hline FY2006 & 16.30 & 6.17 & 9.83 & 14.13 & 4.30 & 9.00 & 6.83 & 59.86 & 95.97 & 2.28 & -6.76 \\
\hline FY2007 & 15.20 & 5.68 & 7.80 & 19.30 & 11.50 & 9.50 & 8.85 & 60.63 & 96.5 & 1.73 & -9.12 \\
\hline FY2008 & 20.50 & 3.70 & 12.00 & 15.30 & 3.30 & 10.00 & 9.20 & 62.55 & 95.39 & 5.06 & 13.50 \\
\hline FY2009 & 21.80 & 1.20 & 20.80 & 9.60 & -11.20 & 13.00 & 10.60 & 78.50 & 94.44 & 5.20 & -5.80 \\
\hline FY2010 & 14.60 & 4.10 & 11.70 & 12.50 & 0.80 & 14.00 & 10.30 & 85.55 & 95.3 & 6.30 & -3.80 \\
\hline Mean (1991-2010) & 13.57 & 4.16 & 9.15 & 14.35 & 5.78 & 12.03 & 8.51 & 50.94 & 101.48 & 4.91 & -3.25 \\
\hline Mean (1991-2000) & 12.48 & 3.42 & 9.16 & 14.12 & 6.12 & 13.95 & 9.70 & 37.51 & 108.88 & 5.87 & -4.01 \\
\hline Mean (2001-2010) & 14.66 & 4.90 & 9.15 & 14.59 & 5.44 & 10.10 & 7.32 & 64.38 & 94.09 & 3.95 & -2.49 \\
\hline SD (1991-2010) & 4.20 & 2.06 & 4.19 & 4.08 & 5.65 & 3.71 & 2.72 & 18.10 & 8.64 & 3.89 & 3.90 \\
\hline
\end{tabular}

$\mathrm{BD}=$ budget deficit, $\mathrm{ER}=$ Pakistan rupee exchange rate, $\mathrm{FY}=$ fiscal year, $\mathrm{M}=$ real growth rate of money, $\mathrm{M}_{2}=$ growth rate of broader measure of money stock, $\mathrm{p}=$ average inflation rate excl. food (core), $R_{C}=$ interbank call money rate, $R_{D}=$ short-term interest rate (discount rate), $R E E R=$ real effective exchange rate, TD = trade deficit as percentage of GDP, ỳ = real growth rate of economy, Yn = nominal GNP growth rate.

Sources: Karachi Stock Exchange, State Bank of Pakistan's annual reports and economic surveys, and the Pakistan Economic Survey. 



\section{Economic Growth (y)}

Economic growth is the principal yardstick measuring macroeconomic performance, either in terms of nominal GDP (Yn) or real GDP (y). A serious investigation of the determinants of growth in the last two decades is far beyond the scope of this paper, but Table 1 (Column 2) provides a brief capsule of information.

The average real growth rate of the economy during the 1990s was 3.42 percent-a low rate for an emerging economy, and one of the lowest among Asian countries (Table 2). This growth rate should be seen in the context of the ongoing technological revolution in the global economy, increases in productivity and efficiency, and the financial sector reforms undertaken in Pakistan. This rate is even lower than the "Hindu rate" (3.6 percent) that marked the 30 years between 1950 and 1980 for the Indian economy, which operated under a Soviet model (Acharya, 1999).

After averaging 3.4 percent, GDP growth accelerated to almost 5 percent during the last decade, but the good news ended after 2007. The overall average real growth rate for the last two decades has been 4.2 percent, and if we subtract the population growth rate of 2.9 percent, the net real growth rate is 1.5 percent, which is the average productivity growth rate for the whole period. How does Pakistan's growth stack up against its peers? It is the lowest among its "peer" group of countries.

Table 2: Growth Trends for Selected Years, 1991-2010

\begin{tabular}{lcccc}
\hline \multirow{2}{*}{ Country } & \multicolumn{2}{c}{ GDP: 1991-2000 } & \multicolumn{2}{c}{ GDP: 2001-10 } \\
\cline { 2 - 5 } & Growth Trend (\%) & Rank & Growth Trend (\%) & Rank \\
\hline China & 10.1 & 1 & $10-11$ & 1 \\
India & 6.1 & 4 & $7-9$ & 2 \\
Indonesia & 5.7 & 6 & $5-6$ & 5 \\
Malaysia & 6.0 & 5 & 6 & 3 \\
Pakistan & 3.4 & 7 & 5 & 7 \\
Republic of Korea & 7.7 & 2 & $4-5$ & 6 \\
Thailand & 7.1 & 3 & 5.5 & 4 \\
\hline
\end{tabular}

GDP $=$ gross domestic product.

Sources: International Monetary Fund's Statistical bulletin and The Economist.

Let us remember that "statistics" are like mud: we can make clay, bricks, or houses out of it. When we look at the data on macroeconomic performance, some numbers show inclines, some declines, and some are 
mixed. What the data omits is as significant as what it conveys. For example, Pakistan's average annual GDP growth rate was 6.80 percent in the 1960s, 4.80 percent in the 1970s, 6.50 percent in the 1980s, 3.42 percent in the 1990s, and 5.02 percent in the 2000s. The earlier higher growth rates were achieved through heavy and continued dependence on external resources such as foreign assistance and remittances. Very little policy attention was given to the structural weaknesses in different industries. Remittances, which had provided the stimulus to the economy during the 1970 s and most of the 1980s, decreased to an average of 5.3 percent of GDP in the 1990s.

Savings and investment remained low at 14-18 percent of GDP during this period. With persistent macroeconomic imbalances, there was also a sharp decline in the availability of external assistance that had played a key role in financing investment until the 1980s. During the latter half of the 1990s, the government introduced a scheme for foreign currency deposits, which was used as a substitute for declining external assistance.

The omissions in the data include societal and systemic factors that stimulate or impede the economy. These include creativity, innovation, entrepreneurship, and new ventures. The numbers also ignore the effects of culture, property rights, laws, and political freedom in the short and long term. The issue of accountability, rule of law, and better governance cannot be exactly measured by the data. If governance in Pakistan had not deteriorated so much, economic performance would not have declined so precipitously in later decades. Considering the last 30 years from 1981 to 2011, governance failures in Pakistan stand out much more than subdued economic growth. Thus, the overall performance picture is far more complex than the simple one portrayed by conventional economic indicators and economic models.

We usually analyze macro-policies from the perspective of economic models - the views of policymakers - with hardly any feedback from the business community. The Business Recorder (26 March 2011) recently documented the view of $\mathrm{M}$. Mansha, a business leader:

What are Pakistan's problems?

The biggest of all are our structural problems, and law and order is inter-related with these structural problems. Then there is a lot of uncertainty; until price distortions are removed, people will not make any long-term investment. 
... The bottom-line is all about competence and good governance. For instance, in case of PSEs, before we sell their strategic shares, we have to pre-qualify the investors to verify their track records. Unfortunately, democracy hasn't worked in this country because the management practices of the politicians are very poor.

... Human capital can and should be our biggest strength. We need a growth rate of 6-8 percent to absorb a rising youth population. And for that, we need to prioritize the industries in which we are going to concentrate. The textile industry is the biggest opportunity for Pakistan to generate employment for the youth, besides earning foreign exchange. The distortions in that industry alone, if removed, would be hugely beneficial to the national economy.

What should be the role of the private sector in education?

I think we need to spend a lot of money on education than we are doing right now. I believe that industrialists need to support them. If the government is building two schools, we should build 20 .

Without going into sectoral details, it is worth mentioning the sources of economic growth and tax contributions for three major sectors for FY2010 (Table 3).

Table 3: Sources of Growth in FY2010

\begin{tabular}{lccc}
\hline Sector & GDP (\%) & Growth (\%) & Taxes (\%) \\
\hline Agricultural & 22 & 2.0 & 1 \\
Industrial & 25 & 4.9 & 63 \\
Services & 53 & 4.6 & 26 \\
Other & & & 10 \\
\hline
\end{tabular}

$\mathrm{FY}=$ fiscal year, $\mathrm{GDP}=$ gross domestic product.

Sources: Pakistan Economic Survey, Federal Bureau of Statistics, Federal Board of Revenue (2010).

There is an imbalance in tax contributions. Certainly, there is a need to increase tax contributions by the agriculture sector-a long overdue reform that lacks political will. The industrial sector seems to be overburdened by tax, but this may not be the case when we look at the structure of tax contribution. 
While the growing importance of the services sector in Pakistan's economic growth is a desired outcome, it also raises issues of plausibility and sustainability. Perhaps a part of the sector's growth in this decade is "spurious" in the sense that it reflects the value-added in huge increases in pay scales over the years, which has put further pressure on our fiscal deficits.

It could also have the unintended consequence of neglecting the significant role of the agriculture sector, which still employs 44 percent of the country's labor force. According to the Government of Pakistan (2010a), "agriculture and livestock are the backbone of this country since they directly employ $44 \%$ of the labor force while two-thirds of the population living in rural areas directly or indirectly depends on these sectors for its livelihood." Pakistan has ignored the potential of agriculture sector development after the 1960s, and that is where the country's economies of scale exist.

It is imperative to address the structural constraints of the economy to long-run sustainable growth. This would provide greater visibility to investors with regard to Pakistan's economic prospects in the medium to longer term, and prove a key catalyst for higher private capital inflows and investment. In this regard, the Government of Pakistan's (2010a) report has some important recommendations worth mentioning:

The universal elements of success have been high rates of domestic savings, an educated labor force with ability to acquire new skills. A committed, focused and evenhanded political leadership and government that ensure availability of global knowledge as a public good and effective institutional framework that ensure competition and functioning of markets and is fiscally responsible, particularly by not borrowing excessively, especially in foreign currency.

... The sector requires support not only for poverty reduction and more equitable development of regions but also to bring more stability in growth in a manner that ensures that the gains in that accrue from this process are safeguarded. Growth biased in favor of the lowest income households will, apart from directly creating employment opportunities, through increased demand for goods and services that are produced domestically are less import intensive and more labor intensive. 
The preceding line analysis omits the important issue of potential growth over time and the gap between potential and actual GDP growth. Some interesting but controversial work has been carried out at PIDE in the last couple of years (see, for instance, Ahmed, 2010; Malik, 2007; Nasir \& Malik, 2011). Although these studies are not conclusive, they seem to persistently suggest that macroeconomic policy has had less success in attaining the economy's output potential in the last 15 years (this is discussed later in the analysis of inflation).

A few observations of future performance are warranted. The GDP growth rate was projected at 1.82 percent for 2010 (PIDE Econometric Model). This could have been due to shocks attributed to the energy shortage, the after-effects of hikes in global food and oil prices, the depreciation of the Pakistani rupee, the global financial crisis, and the deterioration of security, law, and order in Pakistan. However, signs of recovery were expected in 2011 and the real GDP growth rate was projected to approach 6.9 percent by 2013. The average growth rate expected for the period $2009-13$ is 4.08 percent.

Projected trends in the GDP growth rate are shown in Figure 1, although they perhaps overestimate the growth rates of their model, e.g., the actual ex post growth rate for FY2011 was only 2.4 percent, and it is hard to see any significant improvement in the near term. The actual institutional progress has fallen too far short of expectations.

Figure 1: Projected Trends of GDP Growth Rate (2009-13)

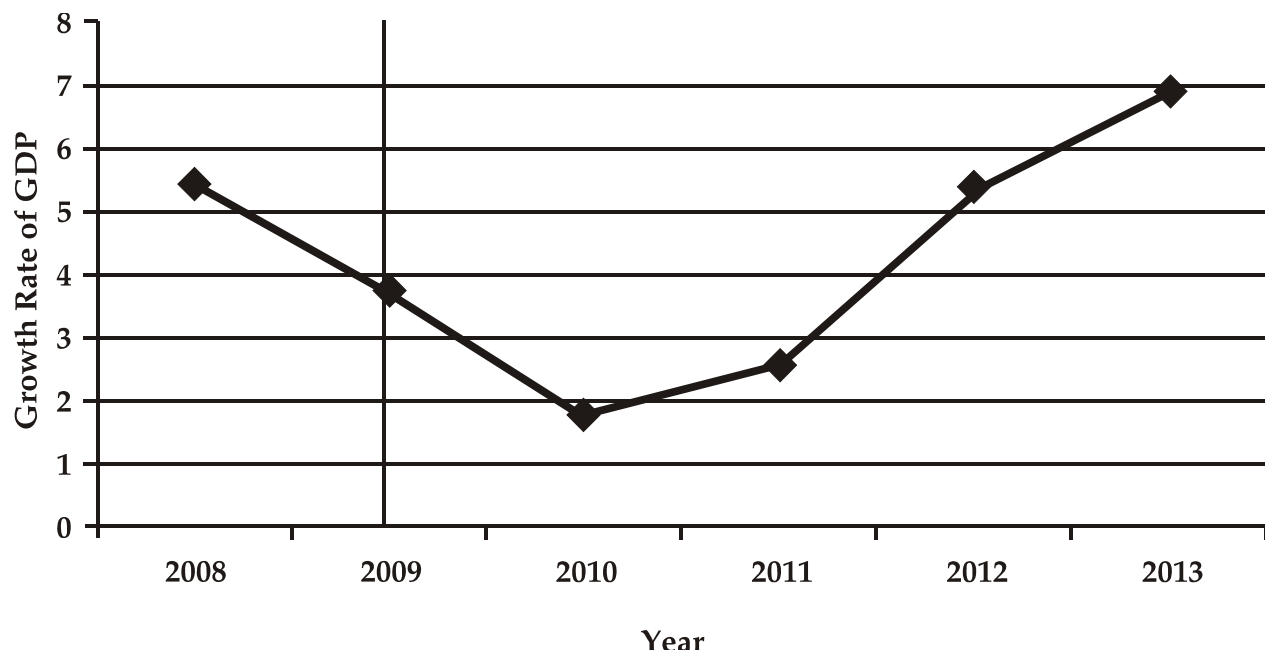

$\mathrm{GDP}=$ gross domestic product.

Source: Adapted from Pakistan Institute of Development Economics (2010). 
A similar projection adopted from the Government of Pakistan (2010a) provides the following framework. As shown in Table 4,

... primary stimulus to growth initially has to come from public investment, while private investment remains depressed, with a likely fall of 7\% in 2009-10. From 201112 , however, it is expected that private investment will start showing double digit growth rates in line with the improvement in conditions, as described above.

Thus, both projections seem to be optimistic.

Table 4: Projection of GDP by Expenditure during Plan Period (Growth Rates)

\begin{tabular}{lccccccc}
\hline Indicator & $\mathbf{2 0 0 9 / 1 0}$ & $\mathbf{2 0 1 0 / 1 1}$ & $\mathbf{2 0 1 1 / 1 2}$ & $\mathbf{2 0 1 2 / 1 3}$ & $\mathbf{2 0 1 3 / 1 4}$ & $\mathbf{2 0 1 4 / 1 5}$ & $\begin{array}{c}\text { Average } \\
\text { (2011-15) }\end{array}$ \\
\hline GDP & & 3.9 & 4.7 & 5.1 & 5.9 & 6.8 & 5.3 \\
$\begin{array}{l}\text { Private } \\
\text { consumption }\end{array}$ & 3.4 & 3.9 & 4.3 & 4.9 & 5.7 & 4.4 \\
$\begin{array}{l}\text { Private } \\
\text { investment }\end{array}$ & -7 & 6.2 & 10.7 & 8.6 & 10.0 & 11.2 & 9.3 \\
$\begin{array}{l}\text { Public } \\
\text { investment }\end{array}$ & & 10.0 & 10.0 & 15.0 & 17.5 & 17.5 & 14.0 \\
\hline
\end{tabular}

GDP $=$ gross domestic product.

Source: Adapted from Government of Pakistan (2010a).

Based on the last few years' experience, the report suggests first, that the economy be gradually restored to a trajectory of high growth from about 3 percent currently to above 6 percent in the next five years. Second, the development strategy to be adopted must focus on achieving inclusive and sustainable growth, not just high rates of growth. This will require keeping the inflation rate under control (especially food prices) and the current account and fiscal deficits within manageable levels, and focusing on a sectoral growth pattern that will create employment for the growing labor force. For the last two years, we have not seen much progress in policy initiatives to achieve these projections. A robust macroeconomic framework is lacking, and implementation of an economic plan is critical.

\section{Inflation $(p)$}

Let us now turn to inflation, the primary enemy of the economy and markets as it creates uncertainty for household consumption and 
business investment. If growth is the key measure of macroeconomic performance, inflation or its absence is generally the preferred indicator of macroeconomic stability. Pakistan has experienced sustained bouts of inflation of 10-24 percent during the last two decades with the exception of a few years in between.

Several studies on inflation in Pakistan-spread over the last two decades-agree broadly on the key factors that influence the rate of inflation: (i) growth in money supply, (ii) supply-side bottlenecks and shocks, (iii) adjustment to government-administered prices, (iv) imported inflation (exchange rate adjustment), (v) escalations in indirect taxes, and (vi) inflationary expectations. However, these studies do not concur on the relative factors that determine inflation. Earlier studies from the 1990s (see, for instance, Hossain, 1990; Nasim, 1995) find money supply to be the principal factor underlying the rising inflation rate in Pakistan. Others suggest that food prices followed by government-administered fuel/energy prices and indirect taxation are the primary impetus for the upward inflationary spiral (see Hasan, Khan, Pasha, \& Rasheed, 1995; Naqvi, Khan, Ahmed, \& Siddiqui, 1994).

A highly regarded study on food inflation in Pakistan by Khan and Qasim (1996) finds that this component of inflation is co-integrated with money supply, value-added in agriculture, and the support price of wheat. Their results suggest that (i) a 10 percent increase in money supply would increase food price inflation by 3.7 percent, (ii) a 10 percent increase in agricultural output would reduce food prices by 6.2 percent, and (iii) a 10 percent increase in the support price of wheat would increase food inflation by 7.4 percent. The role of money supply appears to be significant in influencing food price inflation in Pakistan.

The two main estimated equations in Khan and Qasim (1996) are reproduced below. I am extremely confident that, if these two equations were to be re-estimated to include the later period of 1998-2010, the results would hold even more strongly. Therefore, one can safely conclude that the significance of these factors in determining the inflation rate has increased even more now.

Food price inflation (Khan E Qasim, 1996)

(a) $\quad \ln \mathrm{P}_{\mathrm{f}}=4.31+0.37 \ln \mathrm{M}_{\mathrm{s}}-0.62 \ln \mathrm{yag}+0.74 \ln \mathrm{P}_{\mathrm{s}}$
$(1.83)^{*}$
$(3.97)^{*}$
$(2.22)^{*}$
$(6.71)^{*}$ 


$$
\mathrm{R}^{2}=0.99 ; \mathrm{DW}=1.97 ; \mathrm{SER}=0.06 ; \mathrm{DF}=-4.98^{*} ; \mathrm{ADF}=4.77^{*}
$$

Overall rate of inflation

(b) $\quad \ln \mathrm{P}_{\mathrm{g}}=5.33+0.55 \ln \mathrm{M}_{\mathrm{s}}-0.46 \ln \mathrm{y}_{\mathrm{ag}}+0.46 \ln \mathrm{y}$

$$
\begin{aligned}
& (4.14)^{*} \quad(9.55)^{*} \quad(13.08)^{*} \quad(4.79)^{*} \\
& \mathrm{R}^{2}=0.99 ; \mathrm{DW}=2.49 ; \mathrm{SER}=0.03 ; \mathrm{DF}=-5.83^{*} ; \mathrm{ADF}=5.43^{*}
\end{aligned}
$$

In this respect, what role do monetary policy and the central bank (SBP) play in curbing the inflationary spiral? Given these empirical and heuristic explanations of inflation, the key questions are: (i) What are the primary objectives of the SBP's monetary policy? (ii) Is the SBP's main mandate economic growth or control of inflation? (iii) Does the SBP focus on controlling inflation and several offshoots such as price targets, "inflation targets," credit expansion, and inflationary expectations, etc? (The SBP's policy announces an "inflation target" each year in the annual budget statement.) (iv) How is monetary policy formulated in light of those objectives and how independent is the SBP in asserting and adhering to those objectives? (v) What are the SBP's operational and intermediate targets? (vi) Why are the interbank call money rate (market rate) and policy rate significantly different? These are policy questions and need policy forum discussions, where the SBP can obtain feedback from major stakeholders in the private banking industry, the Planning Commission, institutions such as PIDE, the academic community, and business leaders on the state of economy before announcing its decision on the policy rate.

Another recent theoretical development is the "Taylor rule." Policy debates and empirical estimations have applied this rule to Western and emerging economies (see, for instance, Alper \& Hatipoglu, 2006; Taylor, 1999a; Yazgan \& Yilmazkuday, 2007). Simply put, the Taylor rule is a formula designed to provide recommendations on how a central bank should set the short-term rate as economic conditions change to achieve both its short-term goal of stabilizing the economy and its long-term goal to attain price stability. The basic equation of the rule is:

$$
i_{t}=\alpha_{0}+\alpha_{1} \mathrm{y}_{\mathrm{t}}+\alpha_{2} \pi_{\mathrm{t}}
$$

where $i$ is the short-term policy rate, $y$ is potential output, and $\pi$ is the inflation rate. 
Malik and Ahmed (2010) are probably the first to examine the rationale for applying the Taylor rule to Pakistan, and estimating it for the period 1991-2005 as well as for subsamples of different governors' regimes during that period. They find no evidence that the SBP has ever followed this type of rule. It is a big "charge" for the SBP. The weakness in the study lies, however, in its results from estimating their equation. For the model to be stable, the estimated values of the parameters should be such that $\alpha_{1}>0$ and $\alpha_{2} \geq 1$. However, the estimated value for the output coefficient $(y), \alpha_{1}$, is 0.38 , and for the inflation coefficient, $\alpha_{2}$, is 0.51 ; both coefficients are also significant. As the authors note, this may imply that "the reaction function (eq. 7) is mis-specified." The term $\alpha_{2}$, being substantially lower than 1.0, "implies [the] pro-cyclical response of the monetary policy to the business cycle."

The estimated values of the Malik and Ahmed (2010) model describe an economy that would be unstable. Clearly, that has not happened to Pakistan's economy in the strict sense. The authors seem to realize this and, as they do, note that, "it might also be a reflection of a mis-specified model where important variables have been omitted." They find that, given the level of inflation and output, the Taylor rule would have recommended a much more aggressive monetary policy than that actually set during 1991-2005.

Thus, the validity of the subsequent simulation also becomes blurred when the basic model does not describe the monetary policy well. In view of the likely mis-specified model, the study's conclusions and policy implications may have limited validity. Hence, claims such as that the SBP has not followed the Taylor rule might unnecessarily indict the central bank's policy. In their own words,

Before adopting [a] policy rule it is essential to explore the monetary policy objectives in a country like Pakistan. Literature on the Taylor rule is still inconclusive on the coefficients of variables (other than output and inflation) in the policy reaction function. So a lot of research is needed to reach some firm conclusions on coefficients of these other variables. There is also a need to explore the ways and possibilities for developing countries to adopt more elaborate inflation targeting framework (Malik and Ahmed, 2010).

Nonetheless, one should give credit to Malik and Ahmed (2010) for starting this debate. Research in this area would benefit Pakistan 
where institutions are not yet strong and there is weak focus on issues such as monetary policy transparency and accountability. There could be no better place than the SBP to further this research agenda.

A more recent study by Nasir and Malik (2011) at PIDE provides yet another policy twist in light of the changing nature of monetary policy in the last two decades: "Modern monetary policy is supposed to be forward-looking, and the central banks respond contemporaneously to structural shocks that are expected to make inflation deviate from the future target." They find that policy has a weak response to supply-side shocks as the correlation coefficient between the demand and supply shocks is only 0.041. Their results show that demand shocks make no significant contribution to output fluctuations, but that both demand and supply shocks, along with foreign supply shocks, significantly contribute to inflation variability in Pakistan: "Moreover, domestic supply shock is the central cause of variation of inflation with foreign supply shock at second and domestic demand shock in third place."

The policy implications of their study are: (i) The central bank should be careful in controlling inflation through a tight monetary policy (a continuous message of studies from Islamabad) since an increase in interest rates to reduce domestic demand might not reduce inflation to the desired extent as demand contributes less to inflation; (ii) The cost channel of monetary policy may come into effect, i.e., "the continuous increase in the policy rate by the SBP in recent times is astonishing and rather undesirable" (Nasir \& Malik, 2011). Moreover, a tight monetary policy may not be efficient in the absence of coordination between the demand management policies.

The SBP's current monetary policy stance of raising the policy rate could be justified as follows. Aggregate demand alone cannot explain inflation if the productive capacity of the economy is decreasing, and inflation may persist at the same level of aggregate demand. However, assessing the prevailing output gap is a difficult task for economic managers. It involves judging the capacity or potential of the economy, which is almost impossible to measure.

The behavior of monetary variables, such as the credit demand of the private sector and government sector, can serve as useful indicators of aggregate demand. We know that the government increased the "support price" of wheat. Would we consider this to be a supply shock or a policy decision? Such price increases cannot be considered pure supply shocks. 
The credit extended for "commodity operations," including both wheat and sugar, grew by 288 percent during 2007-10 as compared to 33 percent in the three preceding years. Borrowings on this scale would not have been possible without applying upward pressure on market interest rates. Thus, aggregate demand pressure rises because of the public sector. In response to growing demand pressures, the SBP started tightening its monetary policy stance, and has continued to do so because foreign investment has contracted by 74 percent and net foreign assets have fallen by 37 percent. While aggregate demand has declined, so has the economy's ability to meet this demand and flow of resources from abroad to fill the gap.

In summary, what insight is gained from these studies/commentaries on inflation in Pakistan? The result of PIDE's Econometric Model (2011) predicts that the inflation rate will remain in double digits during 2010-13 (see Table 5). The average inflation rate for 2010-13 will be 14.5 percent. Therefore, a tight monetary policy stance will not have any impact on future inflation. It may be even higher than predicted by the PIDE Econometric Model. Our financial mismanagement is usually good. Despite the model's favorable assumptions, it underpredicts actual inflation by 3-4 percent, as we have ex post inflation data for 2009 and 2010 (see Table 5).

From a personal point of view of monetary policy in Pakistan and inflation rate forecasts, let us remember that behavioral statistics can tell "lies," even if twisted as one might like. Monetary policy is still loose (easy). With any measure of inflation-the consumer price index, producer price index, or gross national product deflator-the actual true inflation rate is higher than the official rate. I do not believe in core inflation as if we do not consume food and energy (if at all available in Pakistan!).

Real rates in Pakistan have been negative for the last 10-15 years. Negative real rates do not imply tight monetary policy. Economies do not produce high real growth rates with negative real interest rates. This is the lesson of the economic history of 1974-2011, and is also supported by the SBP's governor in a recent speech in December 2010 at the chamber of commerce in Karachi. 
Table 5: PIDE Econometric Model Forecast (Out-of-Sample Forecast Results in Percentage Change)

\begin{tabular}{lrrrrrr}
\hline & $\mathbf{2 0 0 9}$ & $\mathbf{2 0 1 0}$ & $\mathbf{2 0 1 1}$ & $\mathbf{2 0 1 2}$ & $\mathbf{2 0 1 3}$ & Average \\
\hline Real GDP & 3.71 & 1.82 & 2.60 & 5.36 & 6.89 & 4.08 \\
Inflation & 14.42 & 13.75 & 13.96 & 14.95 & 15.46 & 14.51 \\
Private consumption & 4.36 & -2.44 & -1.11 & 2.49 & 4.57 & 1.57 \\
Government consumption & 7.43 & 17.81 & 12.32 & 12.41 & 12.71 & 12.54 \\
Private investment & -12.30 & 0.97 & 0.98 & 5.18 & 6.71 & 0.31 \\
Money supply (M2) & 20.29 & 16.03 & 16.09 & 23.09 & 26.17 & 20.34 \\
Export of goods and services & 6.50 & 7.28 & 9.23 & 9.88 & 10.21 & 8.82 \\
Import of goods and services & -6.02 & -1.30 & 0.03 & 3.99 & 6.19 & 0.57 \\
Direct tax revenues & 30.62 & 12.38 & 14.90 & 18.67 & 22.47 & 19.81 \\
Indirect tax revenues & 22.00 & 9.08 & 10.88 & 13.59 & 16.28 & 14.37 \\
\hline
\end{tabular}

GDP $=$ gross domestic product, PIDE = Pakistan Institute of Development Economics.

Note: Negative values indicate a decrease and positive values an increase. The average is taken for the period 2010-13.

On the inflation front, the double-digit growth rates of money supply running at 15-20 percent and projected as being even higher in econometric models' forecasts do not bode well. Simultaneously, growth in BRIC and emerging economies will keep resource and commodity prices high, and inflation and inflationary expectations higher. Pakistan's economy has lived on war dividends that are going to diminish over time in the wake of fiscal belt-tightening among the Western economies.

\section{Budget Deficit, Trade Deficit, and the Exchange Rate}

Looking at its fiscal consolidation over the years, Pakistan's experience with fiscal management has been quite ineffective. The success of monetary policy depends heavily on fiscal support and its prudence. Otherwise, monetary policy is overburdened. The federal government budget deficit as conventionally defined has fluctuated around 5 percent of GDP during the last two decades. In the 1980s, it was 7.1 percent excluding grants, and 6.4 percent including grants. In the last decade, the deficit-to-GDP ratio has decreased to an average of 4 percent.

The real issue in fiscal management is not so much the absolute or percentage changes in data or the Ministry of Finance's accounting maneuverings, but the decomposition of government expenditure on development vs. current expenditure. While development spending generates economic activity and thus reduces the overall debt burden, 
current spending only adds more to the debt burden. The debt data speaks for itself. Over the decades, our internal and external debt has increased. Bukhari and Haq (Business Recorder, 18 February 2011) point out that, in November 2008, the International Monetary Fund (IMF) approved a USD7.6 billion 23-month standby arrangement for Pakistan, which committed to introducing value-added tax (VAT) from July 2010 onward. Much to the IMF's annoyance, the commitment was not honored even by October 2010 and beyond. The finance minister claimed that a huge amount of money had been spent by vested interests to resist reformed general sales tax (RGST), which would have led to the "documentation of [the] economy" and "better tax compliance." It is a fact that the Federal Board of Revenue has failed to improve the tax-to-GDP ratio, which dropped to 8.87 percent in FY2010 from 12.5 percent in FY2002.

Due to inept leadership and corrupt government structures, the country is piling up huge debts-external debt till 2015 is expected to increase to USD75 billion from the current figure of USD55 billion. The country's total foreign and domestic debt at the beginning of 2011 had reached almost USD130 billion. Our financial managers are caught in a dilemma. On one hand, there is mounting pressure from donors to reduce the fiscal deficit through improved collections; on the other, the ailing economy is not in a position to meet the ever-growing revenue targets

It is a pity that, for the latest year, our direct taxes were 3.40 percent of GDP and indirect taxes were 5.48 percent of GDP-a total of 8.88 percent of GDP. Thus, two areas need attention. First, Pakistan's tax base is the lowest among other countries in this region (9-10 percent of GDP). Our dependence on import-related "indirect" taxes is a significant risk to the economy. There is a need to raise the tax-to-GDP ratio to bring it to a minimum of 13-15 percent. This should be vigorously implemented in the under-taxed sector and undocumented areas of the economy, e.g., agriculture, the services sectors, and stock market.

Second, our method of financing fiscal deficit has become a significant threat to the economy and to achieving sustainable growth over the years. This risk stems from the continued reliance of substantial fiscal expansion on the banking system. During 2007-10, the cumulative borrowing from banking increased by 187 percent, as against 58 percent during 2003-07. Within the banking sector, the government has substantially increased its reliance on the SBP for borrowing more than PKR1,500 billion. 
The external sector of Pakistan's economy has been a point of stress for the last 30 years with different degrees of volatility. In the wake of the global financial crisis, emerging economies in our peer-group region have proved much more resilient and recovered more quickly. Pakistan's current account deficit (CAD) as a percentage of GDP is the highest it has been in the last two years. Despite some improvement in the CAD in 2010, it is likely to widen, given the rising trend in international commodity prices and uncertainty of domestic and global recovery. Furthermore, our export growth could slow down as global recovery is expected to slow down. Thus, there seems to be an inherent weakness in Pakistan's external account. The Government of Pakistan's (2010a) report elegantly summarizes this situation as follows:

The present balance of payments crisis (2008) and slow down in GDP growth brings out in sharp relief the historical pattern of Pakistan's growth process. Periods of high growth end due to mounting balance of payments pressures such as at the end of the Ayub period in the 1960s, the Zia period in the 1980s and the recent Musharraf period: High growth has been critically dependent on concessional foreign capital inflows. An export structure that prevents an export growth high enough to finance the import requirements of a high growth trajectory. A domestic savings rate that given Pakistan's existing ICOR is inadequate to finance the investment rate required for a sustained GDP growth of 7 percent.

Among several other studies on exchange rates, Ahmed (2009) examines the role of exchange rate determination in Pakistan and how it impacts a country's macroeconomic stability and the size of its tradable sector. Her conclusion is that Pakistan has "fared poor[ly] on both scores and the situation [has] worsen[ed] in recent years." She notes that, since 2000, "the terms of trade have deteriorated as [the] share of exports in total trade has been small relative to imports." Her hypothesis is that all these trends with a depreciating real exchange rate (RER) should be consistent as predicted by economic theory.

After calculating the equilibrium RER, she finds that it has suffered "from chronic overvaluation in Pakistan between 1\% to $23 \%$ till 2007." One might add that, after the balance of payments crisis of 2008, the depreciation of the Pakistan rupee by almost 42 percent over the last three years may bring this overvaluation to a lower level. This 
overvaluation has occurred due to an increase in foreign remittances and a sharp rise in foreign direct investment in earlier years. This finding provides some explanation for Pakistan's poor experience with macroeconomic stability and its poor performance in the trade sector. The Government of Pakistan's (2010a) report also alludes to a similar view of the overvaluation of the rupee, and suggests measures to

... ease the constraints to growth, especially the financing of the current account deficit, and to enhance the efficiency and competitiveness of the Pakistani economy in general and the heavily protected industrial sector in particular requires continuous and sustainable improvements in total factor productivity. Policy suggestions include interventions like reduction in the anti-export bias in via an undervalued exchange rate regime.

Thus, most studies on exchange rate policy seem to suggest a proactive exchange rate policy to improve the competitiveness of its tradable sector.

\section{The Economics of Institutional Change}

A number of studies have concluded that a society's fundamental political and legal institutions are conducive to growth. Of these, political stability, secure property rights, and legal systems based on the rule of law, are among the most important. Mahoney (2001) finds that the security of property rights is much stronger in nations with common law systems, such as the UK and US. The reasoning is simple. If the police will not help you protect your right to own a home or car, you are less likely to acquire those assets. Similarly, if you cannot easily enforce business or employment contracts, you are far less likely to enter into those contracts. If you cannot plan for the future because you do not know what the rules of the game will be ten years or perhaps even a year from now, you are far less likely to make productive long-term investments that require years to yield returns.

This growing body of literature from economists and social scientists has examined political impediments to the macroeconomic management of developing economies. These explanations include: (i) historical traditions, (ii) socio-structural determinants, (iii) the self-interest of politically powerful sectors, (iv) the entrenched characteristics of a political system, (v) formal properties of political institutions, (vi) the influence of particular economic 
ideologies or schools of thought, (vii) vicious circles, and (viii) a residual category of conjectural factors (see Whitehead, 1990).

These explanations certainly have their merit in the context of Pakistan and can be classified as "political constraints" to the selection of optimal economic strategies. There is ample evidence of the entrenched characteristics of the political system and of vicious circles in Pakistan. Hence, it is imperative to explore macroeconomic stability or instability in developing countries in the absence of appropriate institutions or existence of weaker institutions.

Vulnerability is derived from the notion that, in both dictatorial and democratic regimes, governments can fail; hence, it accelerates the process of market failure, which governments are supported to minimize. Macroeconomic imbalances such as unemployment or recessions are examples of market failure (see North, 1990, 1995). North distinguishes between institutions and organizations. The two examples of organizations are "markets" and "governments." The organization of government is created to prevent market failure. However, what is not realized is that strong government interventions can also lead to government failure.

According to North, a consistent shortcoming of several approaches to macroeconomic (classical, neoclassical, Keynesian, monetarist, and rational expectationist, etc.) is the inadequate focus on institutions-hence, the New Institutional Economics (NIE). The NIE literature shows that the most important determinant of sustained growth is the institutional structure within which growth occurs. The predominant paradigm in the 1950s and 1960s was the primacy of governments over markets. The stagflation of the 1970s demonstrated that market interventions can lead to government failures. As the damage wrought by government failure was established in the 1980s, the response was a full-fledged attack on the role of the government (Friedman, Thatcher-Reaganism, supply-side economics, the IMF and World Bank). In the presence of weak political systems and market imperfections lies the need for "institution building."

This analysis suggests that government failures can be rampant in both democratic and dictatorial regimes. In the context of Asian economies, Chowdhury (1996) finds that the macroeconomic performance of weak states is inferior to that of strong states, and the result is macroeconomic crisis. Whether a state is "strong" or "weak" depends on the historical, cultural, and geopolitical factors mentioned earlier by Whitehall (1991). 
In Pakistan, three important organizational branches that affect macroeconomic policy and growth are the bureaucracy (Ministry of Finance, the Planning Commission), the central bank, and the parliament. Institutional change must occur first in these organizations. If government interventions are necessary, market pricing should be given priority with a clear focus on providing transparency and accountability (e.g., sugar pricing in 2010). The state can still provide a long-term vision and direction to the economy, but this is only possible if both governance and public institutions are strong. The political sector should prevent "coalition governments" where minority parties hold the balance of power (e.g., on the issue of RGST). Coalition governments may not be conducive to swift fiscal reforms when they are needed (Alesina, 1992).

We could make a long list of the sources of government failure, which might include poor administrative capacity, overzealous regulations, rent-seeking behavior, inefficient political cycle(s), poor governance, and lack of transparency and accountability. The main emphasis of NIE is the quality of governance, which is the key to success. Poor governance has been at the heart of most economic failures in Pakistan. To achieve good governance, a country must have reasonable political stability and a political leadership that respects the rule of law, a bureaucracy that is honest and efficient, and the political will to mobilize resources for an effective government.

Sequentially, the reform process should begin with the central bank being given a clear mandate of price stability to enhance macroeconomic performance (Alesina \& Summers, 1993). The central bank's authority should be amended to give it a mandate to solely control inflation rather than a host of conflicting objectives to enhance accountability and transparency. The central bank's independence extends to "instrument independence," not "goal independence."

Let us look at the SBP's experience as an "institution" with reference to its policy setting and achieving this goal. An excellent study by Malik and Din (2008) shows that monetary policy transparency requires the central bank to disclose information that is relevant to the conduct of monetary policy, and symmetric information between the central bank and private economic agents (Geraats 2002, 2005). In addition, transparency does not require perfect knowledge of the economy as both the central bank and public may have imperfect information regarding shocks to the economy. 
A transparent monetary policy has several benefits, such as increased public support for central bank policies, and the legitimacy of monetary policy. It also helps improve the efficiency of the central bank and increase transparency, which helps reduce uncertainty in financial markets, thereby improving long-run growth prospects. A high degree of transparency forces the central bank to adhere to its stated objectives and targets, thus increasing its credibility. Thus, transparency lies at the heart of the central bank's independence and accountability.

Malik and Din (2008) evaluate the SBP's monetary policy transparency using the Eijffinger and Geraats (2006) index, and compare Pakistan's transparency practices to those of eight other countries, using a 15 -point scale. According to the their results, Pakistan scores only 4.5 out of 15, ranking last among those included in the comparative index. The study is highly critical of the fact that the targets for the SPB's goalsprice stability and output growth-are not set by the SBP but by the government. However, the SBP does not prioritize these goals, which compromises its independence, at least with regard to goal setting.

The one-year-or-less timeframe used to report goals is further problematic because "the lag with which monetary policy actions affect the outcome (inflation) is normally greater than one year." On the positive side, the IMF (2010b) notes that the SBP has achieved a range of improvements, from the modernization of its information technology system to enhanced professional staffing, all of which should have a positive impact on the country's monetary policy transparency.

To be fair to the SBP, Malik and Din (2008) are comparing its transparency with the most advanced countries' central banks that have a much longer history and maturity in monetary policy setting. Another comparison of central banks among "peer" group of countries is given in the IMF's reports on the observance of standards and codes. These evaluate the extent to which countries observe certain internationally recognized standards and codes. The reports cover banking supervision, corporate governance, data dissemination, and monetary and financial policy transparency. It is clear that, while other countries have improved, Pakistan's performance remains constant. 


\section{Figure 2: Code of Good Practices on Transparency in Monetary Policy}

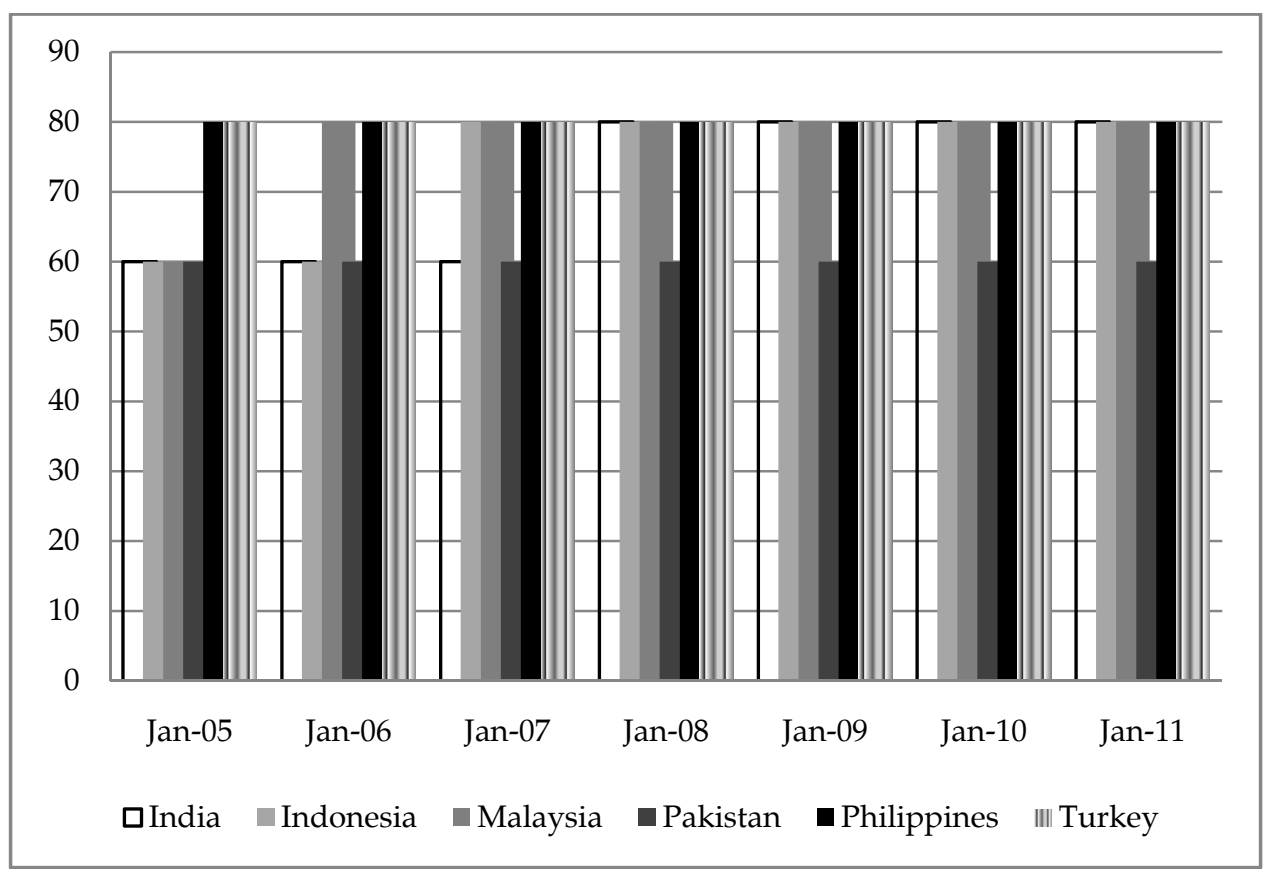

Source: International Monetary Fund. (2011). Pakistan: Financial system stability assessment.

\section{Economic Vulnerability and Resilience}

In the wake of the growing importance of institutional economic explanations of growth, the literature has developed several models and indices to assess the role of institutional variables. In this strand, one emphasis is on economic vulnerability and resilience. The term "resilience" is generally understood to mean the ability to recover quickly from the effect of an adverse incident. ${ }^{1}$ As Briguglio, Cordina, Farrugia, and Vella (2009) note, the term has been used in the economic literature in at least three senses relating to the ability to (i) recover quickly from a shock"shock counteraction," (ii) withstand the effect of a shock-"shock absorption," and (iii) to "avoid" shock as the obverse of economic vulnerability.

In his conceptual framework, Briguglio (2004) identifies four possible categories into which countries can be classified according to

\footnotetext{
${ }^{1}$ Merriam-Webster defines resilience as (i) the capability of a strained body to recover its size and shape after deformation caused especially by compressive stress, (ii) the ability to recover from or adjust easily to misfortune or change; origin, Latin resilire, to jump back, recoil.
} 
their vulnerability and resilience characteristics. He terms these "bestcase," "worst-case," "self-made," and "prodigal son."

- "Self-made" countries have a high degree of inherent economic vulnerability, but have adopted offsetting policies to build their economic resilience, thereby reducing their overall exposure to external shocks.

- Countries termed "prodigal sons" are characterized by a relatively low degree of inherent economic vulnerability, and have adopted policies that increase their exposure to exogenous shocks.

- The "best-case" countries are not inherently highly vulnerable, and have also adopted resilience-building policies.

- The "worst-case" countries are highly vulnerable, and have also adopted policies that exacerbate the negative effects of their vulnerability.

These four cases are illustrated in Figure 3, where inherent economic vulnerability and nurtured resilience are measured on the horizontal and vertical axes, respectively. Where does Pakistan stand in this classification? Without any hesitation, the answer is "worst-case."

Figure 3: Four Economic Scenarios

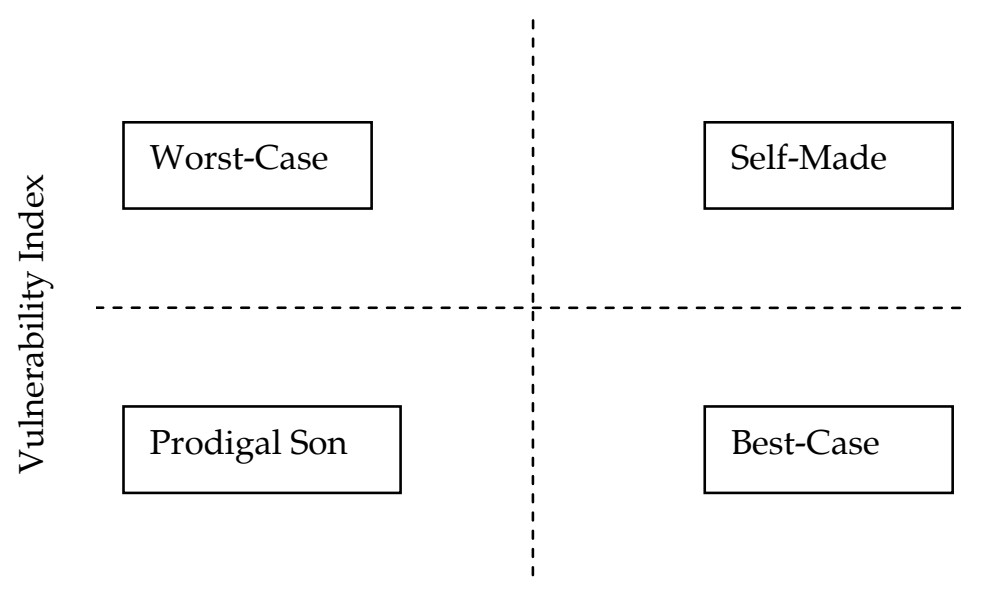

Resilience Index 


\section{Governance Indicators}

In order to capture the governance environment in different countries, the World Bank has developed aggregate governance indicators as follows:

1. Voice and accountability (VA): The extent to which a country's citizens are able to participate in selecting their government, as well as freedom of expression, freedom of association, and a free media.

2. Political stability and absence of violence $(P V)$ : Perceptions of the likelihood that the government will be destabilized or overthrown by unconstitutional or violent means, including political violence and terrorism.

3. Government effectiveness (GE): The quality of public services, the quality of the civil service and its degree of independence from political pressures, the quality of policy formulation and implementation, and the credibility of the government's commitment to such policies.

4. Regulatory quality $(R Q)$ : The ability of the government to formulate and implement sound policies and regulations that permit and promote private sector development.

5. Rule of law (RL): The extent to which agents have confidence in and abide by the rules of society, and in particular the quality of contract enforcement, the police, and the courts, as well as the likelihood of crime and violence.

6. Control of corruption (CC): The extent to which public power is exercised for private gain, including both petty and grand forms of corruption, as well as "capture" of the state by elites and private interests.

This study does not look empirically at these six performance indices for Pakistan, but it could be a potential graduate thesis topic ("That is why God made graduate students," Solow, 1972). However, Uppal (2011) looks at some of these indicators and their performance for other countries.

The anecdotal evidence suggests that Pakistan has not performed well on most of these governance issues, nor has it been able to match pace with the high-performing Asian economies despite its considerable 
potential and large inflow of financial resources. It is usually observed that foreign aid cannot be the driver of high economic growth. At best, aid is "secondary." According to Hasan (2011), "the countries that benefitted from foreign aid are those who knew where they wanted to go and were willing to make tough choices to achieve their goals, e.g., Korea, Turkey, Indonesia and Malaysia." Pakistan's excessive external dependence, high defense spending, and an active military role in national politics have been the root cause of its inability to achieve sustained economic growth. With the deterioration of the quality of governance over time, public institutions too have been eroded.

\section{Pakistan's Challenges}

I have already touched on some of the systematic and systemic risks to the economy. There is no shortage of challenges. However, I will focus on a few important ones. Pakistan's experience with macroeconomic management in general and fiscal and monetary policy in particular, has been inconsistent. Many scholars have documented this and I have expanded on some of these in this study. Judging by the evidence, we have observed high inflation rates, fluctuating growth, high unemployment rates, highly volatile rates of inflation, low growth, and volatile exchange rates as compared to peer countries.

Within a macroeconomic framework, both at a theoretical and empirical level, there is now near-consensus among economists and even policymakers on the following four propositions (although there is still disagreement on the operational mechanisms):

1. Prolonged and pronounced inflationary deficit financing should be excluded as a deliberate instrument of growth.

2. Monetary policy should be directed to price stability and be used for short-term output fluctuations in extreme conditions.

3. Adjustments to external shocks require both absorption and production responses.

4. Exchange rates should not be misaligned for a prolonged period of time.

These propositions can more or less be classified as the "systematic" challenges faced by all economies. Economics is a dismal science, further obscured by the onslaught of globalization forces and competition since the early 1980s. Naturally, some forecasts lack accuracy 
and precision because global economies have traded jobs for profits through outsourcing. Time and chance also influence economic events. Thus, systematic challenges have to be resolved by using an optimal combination of fiscal and monetary policies, and effective planning.

Friedman $(1963,1968)$ recommended long ago that money growth be left alone. "Money is a veil" and acts as grease to lubricate the economy and follow a stable monetary growth. What we see are ad hoc attempts to actively intervene in the monetary sector in Pakistan. Do we follow the Taylor rule? According to the evidence, we do not. If so, why? The SBP needs to spell out its reasons to the public and other stakeholders. Have we worked on improving the policy formulation process and strengthening economic and political institutions? In the 2000s, state institutions were politicized, and the National Accountability Bureau was willing to ignore cases (e.g., in 2005, an inquiry by the Securities and Exchange Commission of Pakistan [SECP] into charges of manipulation at the Karachi Stock Exchange was totally dismissed).

\section{Fiscal Policy}

On the fiscal policy front, our usual challenge is to increase our tax base from direct taxes. What is even more important is the tax structure itself. "Why is the government subsidizing power to the public through SOEs? If it must, it should subsidize through its fiscal budget," says business leader Altaf Saleem. "Policy liberalization in Pakistan was much faster, as compared to India. Yet investments did not flow. The prime reason was unclear and inconsistent corporate tax policy." (I refer again to the role of "institution building" and devising and implementing fiscal and monetary instruments and strategies to finance our prolonged budget deficits.) On the fiscal front, Ikram (2011) puts a heavy burden on the Federal Board of Revenue and its lack of administrative capacity.

\section{Monetary Policy}

Monetary policy can help fiscal policy raise capital for the government by developing a bond market. Several questions arise in this respect:

- Why does the SBP rely heavily on the issuance of short-term treasury bills? 
- What operational difficulties hamper the development of an investment bonds market?

- What steps are being taken by the Ministry of Finance, SBP, and SECP to develop a bond market?

- What are the impediments to developing a meaningful "yield curve" in Pakistan?

- Why has the yield curve in Pakistan been almost flat over the last five years and even slightly negatively sloped in the last decade? A negatively sloped yield curve can predict recessions.

- What have we done in terms of policy to improve the process of "financial intermediation" to attract domestic savings for productive investments?

- Why does the spread between lending and deposit rates in the Pakistan banking industry diverge so largely?

- Despite 30 years of implementing Islamic banking, we have not attracted investment through true long-term instruments such as musharaka and mudaraba. The practice is nothing more than a mark-up mechanism based on conventional interest rates.

In the corporate sector and stock market, the SECP faces several challenges:

1. The development of investment bond and corporate bond markets.

2. The role of the stock market in providing liquidity, price information, and efficiency; and the ability to raise funds in the capital market.

3. In the last five years, the Pakistan capital market has issued one IPO of PKR200 million, whereas India issued more than USD30 billion in the autumn of 2010 alone.

All these issues are related to institutional and regulatory failures in Pakistan. 


\section{Industrial Policy}

The industrial sector contributes to 25 percent of Pakistan's GDP. It was the largest consumer of energy in the last decade, followed by transport, residential, and commercial consumers, agriculture and others. Investments in energy were clearly neglected and the ability of the industrial sector to use RER adjustment was postponed. Cotton textiles production and apparel manufacturing are the largest industries, accounting for about 66 percent of merchandise exports and almost 40 percent of the employed workforce. Yet the international competitiveness of the textiles sector remains fairly mediocre.

Even in the heyday of 2000-07, when fiscal borrowing was curtailed, interest rates were relatively low, and inflation was in check, (although I would disagree with the data), there was confidence in the domestic currency. Yet there was no worthwhile industrial development in this decade. The only industries that expanded were those that were heavily subsidized. The prerequisites of industrialization include geographical advantage, a stable economy, presence of raw material, and most importantly, skilled human capital. The possibility of errors is embedded in any policymaking process; what matters is consistency.

There is no single formula that a country can simply adopt to achieve sustained growth. However, three sectors that face greater challenges and have the capacity to improve include international trade, agriculture, and human development. I will briefly comment on trade.

\section{International Trade}

Economic growth does not proceed smoothly. Economic crises often occur. For instance, in the last five years, almost 2.5 percent of GDP growth was reduced by losses in terms of trade. Unfortunately, the 21st-century world in which we live is neither flat nor merciful: "Our range of merchandise exports and SMEs are essentially labor intensive with relatively higher employment elasticities" (Government of Pakistan, 2010a).

The Government of Pakistan's report (2010) makes an excellent case for regional trade opportunities and challenges. It is a pity that Pakistan's official bilateral trade with India is only around USD2 billion. Pakistan and India account for almost 90 percent of South Asia's GDP. Low bilateral trade is an important constraint to the growth of South Asian exports to the rest of the world. There are several advantages of normalizing trade 
between the two countries. Geographical proximity, cheaper transportation costs, low levels of inventories of raw material, and reduced costs of operations are a few areas in which potential advantages could help realize normalize trade. The report also enumerates several macroeconomic advantages such as trade deficit, inflation, reduced cost of investment, and the fear of Pakistan's manufacturing industry.

Finally, there is the "new paradigm" - the biggest challenge facing Pakistan's economy. Our main shortfalls are due to our failure to guard against internal and external vulnerabilities that make Pakistan less resilient to shocks. This has two aspects.

Systemic risk assessment and management

Systemic risk relates to risk arising from internal shocks such as the floods of 2010, the earthquake of 2005, and energy shortages, and from external shocks such as fluctuations in foreign remittances, the threat of capital controls, a decline in foreign economic assistance, global financial crises, and recent EU debt issues. Other internal shocks are due to institutional failure. Some recent examples of institutional failure include the badla-related stock market crash (2005), the closure of markets for four months in August 2008, the failure of cooperative societies, and accumulation of nonperforming loans in our banking system. The main challenge is finding the capacity to foresee these systemic risks. The political process and lack of institution building have put Pakistan in this situation.

\section{Building resilience to shocks}

In Section 3, we examined some indicators of good governance and building resilience. There could be emerging vulnerabilities. An imminent threat is the drastic drop in external assistance coupled with sanctions, trade restrictions by Western economies, heavy reliance on foreign remittances, and prolonged internal conflict born out of the war on terrorism. How prepared are we for these emerging vulnerabilities?

The last two decades have seen poor macroeconomic management. Negative external and internal shocks have significantly reduced the economy's growth rates toward 2-3 percent. Fiscal and monetary policies have remained expansionary, and structural reforms have been postponed. Hasan (2011) provides the following intermediate prospect for Pakistan: 
Under the present circumstance, it is clear that a strong revival of the economy presupposes a restoration of law and order and rule-based governance. In other words, at the moment, the non-economic issues are the one that seem most intractable. A quick and strong turnaround in economic growth does appear problematic in the best of circumstances. The elimination of macroeconomic imbalances would continue to constrain growth in domestic demand for some time.

Restoring strong export competitiveness would also take time because of the lag in education and skills. In any case, international economic conditions may remain difficult and limit the growth in world trade. On the supply side, the constraints imposed by the scarcity of water and power and other infrastructure are very real. But the economic prospects for Pakistan in the medium and long run appear excellent, if strong economic policies and a pragmatic approach is taken to issues of the respective roles of the state and the market and if governance and security problems are brought under control (p. 461).

One hopes that his assessment is correct. 


\section{References}

Acharya, S. (1999). Managing external economic challenges in the nineties: Lessons for the future (Occasional Paper No. 33). Colombo: Central Bank of Sri Lanka.

Ahmed, H. (2009). Capital flows and real exchange rate overvaluation: A chronic ailment: Evidence from Pakistan [Special edition]. Lahore Journal of Economics, 14, 51-86.

Alesina, A. (1992). Political models of macroeconomic policy and fiscal reform (Policy Research Working Paper No. 970). Washington, DC: World Bank.

Alesina, A., \& Summers, L. (1993). Central bank independence and macroeconomic performance. Journal of Money, Credit, and Banking, $25,151-162$.

Alper, E., \& Ozan, H. (2006). Taylor rule estimation in emerging markets [Working paper]. Istanbul, Turkey: Bogaizici University, Department of Economics.

Amjad, R. (2003). Solving Pakistan's poverty puzzle: Whom should we believe? What should we do? Pakistan Development Review, 42(4), 375-393.

Bhanumurthy, N. R., \& Kumawat, L. (2009). External shocks and the Indian economy: Analyzing through a small structural quarterly macroeconomic model. New Delhi, India: National Institute of Public Finance and Policy. Retrieved from http://mapra.ub.unimuenchen.de/19776

Briguglio, L. (2004). Economic vulnerability and resilience: Concepts and measurements. In L. Briguglio \& E. J. Kisanga (Eds.), Economic vulnerability and resilience of small states. Malta: Islands and Small States Institute.

Briguglio, L., Cordina, G., Farrugia, N., \& Vella, S. (2009). Economic vulnerability and resilience: Concepts and measurements. Oxford Development Studies, 37(3), 229-247. 
Chaudhary, M. A., \& Waseem, S. (1996). Fiscal policy and sustainability of debt, deficit and inflation in Pakistan [Working paper]. Islamabad, Pakistan: Quaid-i-Azam University, Department of Economics.

Chishti, S. U., Hasan, M. A., \& Mahmud, S. F. (1989). Macroeconomic policies and Pakistan's economy. Pakistan Development Review, 28, 717-730.

Chowdhury, A. (1996). Macroeconomic management in East Asian newly industrializing economies. In B. Kapur, E. Quah, \& H. T. Hoon (Eds.), Trade and development, and the Asia-Pacific. Singapore: Prentice-Hall.

Cordina, G. (2004a). Economic vulnerability, resilience and capital formation. In L. Briguglio and E. J. Kisanga (Eds.), Economic vulnerability and resilience of small states. Malta: Islands and Small States Institute.

Cordina, G. (2004b). Economic vulnerability and economic growth: Some results from a neoclassical growth modeling approach. Journal of Economic Development, 29(2), 21-39.

Eijffinger, S. C. W., \& Geraats, P. M. (2006). How transparent are central banks? European Journal of Political Economy, 22(1), 1-21.

Geraats, P. M. (2001). Transparency of monetary policy: Does the institutional framework matter? [Mimeo]. Cambridge, UK: University of Cambridge.

Geraats, P. M. (2002). Central bank transparency. Economic Journal, 112, F532-F565.

Government of Pakistan. (2010a). Final report of the Panel of Economists: Medium-term development imperatives and strategy for Pakistan. Islamabad, Pakistan: Planning Commission.

Government of Pakistan. (2010b). Pakistan economic survey 2009-10. Islamabad: Finance Division.

Haque, N. (2010, December). Can Pakistan grow faster? Paper presented at the Quaid-i-Azam Lecture, 26 ${ }^{\text {th }}$ Annual Conference of the Pakistan Society of Development Economists, Islamabad. p. 45. 
Haque, N., \& Montiel, P. (1992). Fiscal policy in Pakistan since 1970 (Working Paper No. 92/97). Washington, DC: International Monetary Fund.

Hasan, P. (2011). My life, my country. Lahore, Pakistan: Ferozsons.

Hasan, M. A., Khan, A. H., Pasha, H. A., \& Rasheed, M. A. (1995). What explains the current high rate of inflation in Pakistan? Pakistan Development Review, 34(4), 927-943.

Hossain, A. (1990). The monetarist versus the neo-Keynesian view on the acceleration of inflation: Some evidence from South Asian countries. Pakistan Development Review, 29(1), 19-32.

International Monetary Fund. (2010a). World economic outlook database. Washington, DC: Author.

International Monetary Fund. (2010b). Pakistan: Third review under the stand-by arrangement. Washington, DC: Author.

Kardar, S. (2007). Monetary and fiscal policies [Special edition]. Lahore Journal of Economics, 12, 43-65.

Khan, A. H., \& Qasim, M. A. (1996). Inflation in Pakistan revisited. Pakistan Development Review, 35(4), 747-759.

Khan, M. A., \& Din, M. (2011). A dynamic macroeconometric model of Pakistan's economy (Working Paper No. 69). Islamabad: Pakistan Institute of Development Economics.

Khan, S., \& Khan, M. A. (2007). What determines private investment? The case of Pakistan (Working Paper No. 36). Islamabad: Pakistan Institute of Development Economics.

Little, I., Cooper, R., Corden, M., \& Rajapatirana, S. (1993). Booms, crisis and adjustment: The macroeconomic experience of developing countries. New York, NY: Oxford University Press.

Mahoney, P. G. (2001). The common law and economic growth: Hayek might be right. Journal of Legal Studies, 30(2), 503-525. 
Malik, W. S. (2007). Monetary policy objectives in Pakistan: An empirical investigation (Doctoral dissertation). Pakistan Institute of Development Economics, Islamabad.

Malik, W. S., \& Ahmed, A. M. (2010). Taylor rule and macroeconomic performance in Pakistan. Pakistan Development Review, 49(1), 3756.

Malik, W. S., \& Din, M. (2008). Monetary policy transparency in Pakistan: An independent analysis (Working Paper No. 44). Islamabad: Pakistan Institute of Development Economics.

McKibbin, W. J., \& Sachs, J. D. (1991). Global linkages: Macroeconomic interdependence and cooperation in the world economy. Washington, DC: Brookings Institute.

Mundell, R. A. (1999, December). A reconsideration of the twentieth century (Document No. 1999-5). Nobel Prize in Economics documents. Nobel Prize Committee. Retrieved from http:/ / www.nobelprize.org/nobel_prizes/economics/laureates / 1999/mundell-lecture.pdf

Naqvi, N. H. (2002). Crowding in or crowding out? Modeling the relationship between public and private fixed capital formation using cointegration analysis: The case of Pakistan 1964-2000. Pakistan Development Review, 41, 255-276.

Naqvi, N. H., Khan, A. H., Ahmed, A. M., \& Siddiqui, R. (1994). Inflation in Pakistan: Causes and remedies. Islamabad: Pakistan Institute of Development Economics.

Naqvi, N. H., Khilji, N. M., \& Ahmed, A. M. (1983). The PIDE macroeconomic model of Pakistan's economy. Islamabad: Pakistan Institute of Development Economics.

Nasim, A. (1995). Determinants of inflation in Pakistan. Karachi: State Bank of Pakistan.

Nasir, M., \& Malik, W. S. (2011). The contemporaneous correlation of structural shocks and inflation: Output variability in Pakistan (Working Paper No. 70). Islamabad: Pakistan Institute of Development Economics. 
North, D. (1990). Institutions, institutional change and economic performance. Cambridge, UK: Cambridge University Press.

North, D. (1995). The New Institutional Economics and third world development. In J. Harries, J. Hunter, \& C. M. Lewis (Eds.), The New Institutional Economics and third world development. New York, NY: Routledge.

Pasha, H., et al. (1995). Integrated social policy and macroeconomic planning model for Pakistan. Karachi, Pakistan: Social Policy and Development Centre.

Qayyum, A. (2005). Modeling the demand for money in Pakistan. Pakistan Development Review, 44, 233-252.

Rashid, A. (2005). Public/private investment linkages: A multivariate cointegration analysis. Pakistan Development Review, 44, 805-817.

State Bank of Pakistan. (2010). Annual report 2009-2010. Karachi: Author.

Taylor, J. B. (1999a). Introduction in monetary policy rules. Chicago, IL: Chicago University Press.

Taylor, J. B. (1996b). A historical analysis of monetary policy rules. In J. B. Taylor (Ed.), Monetary policy rules. Chicago, IL: Chicago University Press.

Whitehead, L. (1990). Political explanations of macroeconomic management: A survey. World Development, 18, 1133-1146.

Woodford, M. (2001). The Taylor rule and optimal monetary policy. American Economic Review Papers and Proceedings, 91, 232-237.

Yazgan, M. E., \& Yilmazkuday, H. (2007). Monetary policy rules in practice: Evidence from Turkey and Israel. Applied Financial Economics, 17(1), 1-8. 